UDC 681.2.088-049.6:[622.012:658.562]

D.V. BROVKO, Cand. Sc. (Eng.), Assoc. Prof., Head of Research Department, V.V. KHVOROST, Cand. Sc. (Eng.), Assoc. Prof., V. Yu. TYSHCHENKO, Research Assoc., Kryvyi Rih National University

\title{
RELIABILITY CORRECTION WHEN DETERMINING SAFE OPERATION OF MINE SURFACE OBJECTS RELATED TO THE BASIC PRODUCTION PROCESS
}

Purpose. To develop the method for determining the technical condition of the structural elements of surface mine objects, which allows for minimum correction in reliability levels and ensures the highest safety standards of the mine facilities.

Methodology. An analytical model for determining the building physical wear at a diagnostics of the mine surface object was developed, and its actual survivability was found. In order to determine the standard reliability levels, the object is represented as a system of hierarchically sequentially connected groups of bearing elements of the same type. When modeling, the main parameters like the actual state and the survivability degree of the structural elements were considered.

Findings. A model law of the building state is obtained in the form of the dependence of the wear of the bearing elements on its survivability. The threshold values of survivability are determined, at which the surface mine object passes into a qualitatively different state - from normal to satisfactory, from satisfactory to unsuitable, and from unsuitable to emergency. The proposed methodology for assessing safety of the operated buildings and surface structures can be used in practice to assess the degree of survivability, the type of technical state and a safe residual resource.

Originality. The scientific novelty of the method proposed consists in an adequate description of the technical state of the bearing elements of buildings and mine facilities, which takes its place among the new modern experimental studies of materials and structures of surface objects.

Practical value. The method enables to determine the object survivability at diagnostics, its technical state and safe residual resource. The mentioned activities increase safety of the operated facility, hence, ensure the preservation of both lives of the company's employees and tangible assets.

Keywords: mine surface objects, reliability, survivability, qualimetric assessment.

doi: 10.31721/2306-5435-2019-1-105-14-18

Problem statement. Industrial surface objects at the mining enterprise related to the production processes are considered as a complex construction, representing an organized set of the identical constructions similar to foundation, walls, overlap, etc. The standard values of survivability are the average values at which the structural elements of the surfaces in mines pass into a different technical state. They are used to formulate the safety requirements for buildings and structures in assessing their technical condition.

Unsolved part of the problem. Modern science and production are based on the standard methods for determining the current condition of the structural elements. The standard values of the survivability include the following:

normal survivability, which regulates the survivability value of the object after completion of construction work;

satisfactory survivability, at which the mine surface object passes from the normal to the satisfactory condition. Repair works of the object are required;

unusable survivability, at which the object passes from the satisfactory to the unusable condition. The ability of the object to resist the loads acting on it is decreased. Repair and restoration works are required;

emergency survivability (crash), at which the mine surface object passes from the unusable to the emergency condition. The ability of the object to resist the loads acting on it is decreased and operation is strictly prohibited. At a time, the development and implementation of new techniques on a comprehensive determination of the current condition of the surface objects prolongs their safe operation.

Analysis of research and publications. The works of scientists V.V. Bolotin, A.R. Rzhanitsyn, A.G. Roitman, V.D. Raiser contributed to the development of methods of reliability theory in construction.

Holicky M., Diamantidis D., Sykora M., Johan V. Retief, Celeste V. [1, 2] define modern criteria for designing structures that provide a wide range of reliability indicators for different base periods of existence of objects, even if their calculation for different base periods is uncertain through the inter-

(C) Brovko D.V., Khvorost V.V., Tyshchenko V. Yu., 2019 
dependence of failures. General approaches to the choice of reliability levels are discussed from the point of view of optimizing costs and human security. The target effects of cost reduction and the consequences of failures on security measures are considered. The issues of bridging the gap between probabilistic and operational evaluation at design are addressed. It was suggested that improved reliability principles and models could contribute to the further development of international standardization of construction [3, 4]. The works of K.M. Chaminda Konthesinghaa, Mark G. Stewarta, Paraic Ryana, John Gingerb, David Hendersonb [5] are devoted to the development of a vulnerability model for predicting the probability and damage degree to metal lining of industrial buildings under extreme wind loads. The model uses structural reliability methods to describe the spatial distribution of wind load. In the work "Research on Industrial Building's Reliability Assessment Based on Projection Pursuit Model" Zhang Lei and Jie Liu presented a model of industrial building reliability based on the classification of observation results. Optimum values are obtained using the composite simplex method. The 3 factors, selected as a system of evaluation indicators, were identified from 11 affected the reliability of the industrial building.

It is often impossible to assess the influence of the whole range of the listed factors theoretically. Modern experimental studies on materials and building structures are therefore of heightened relevance.

Previously unsolved part of the general problem. The technical condition of the structural elements of buildings is assessed by comparing the maximum permissible (calculated or normative) and actual values characterizing strength, stability, deformability and performance of structures.

The properties of building materials, bases, loads and impacts, operating conditions are the determining factors when assessing the technical condition of a surface object. The method of limit states as a basis for calculating structures takes into account a statistical nature of the indicators in calculation, as well as an impact of various operational factors through the appropriate reliability factors. The limit states method is a semi-qualitative method for calculating reliability. It includes the probabilistic methods for normalizing the strength of materials, operating loads and reliability coefficients, and the strength is calculated in deterministic form. Therefore, the method of limit states does not allow for a comprehensive understanding of the survivability of the operated object.

Formulation of the objective. The main methods for determining the object survivability can be distinguished:

technical;

organoleptic;

calculated.

A qualimetric assessment used for calculating the survivability of the surface object, that meets all the security requirements, ensures accident-free operation.

The use of the qualimetric assessment methods entails high-quality performance, minimizes correction in reliability levels and ensures high safety standard of the mine facilities.

Presentation of the main material. Unlike the standard survivability values, the standard reliability levels of elements groups are not constant. In order to determine the standard reliability level, an object is considered as a system of hierarchically and serially connected groups of the identical bearing elements. We assume that human errors committed in one of the groups do not depend on the errors made in other groups. Hence, we apply methods of the system reliability theory [1,2], in order to assess $v$ as a mine object reliability. The result is

$$
v=\prod p_{n},
$$

where $\prod p_{n}$ is the work of the reliability levels of all groups of object elements.

To determine the average value of the survivability we should use the ratio resulting from (1)

$$
R=\frac{1}{M_{v}}
$$

where $M_{v}$ is the average value (mathematical expectation) of a random variable, the numerical values of which range from 0 to 1 .

The analogy between the destruction of the elements and signals about their destruction is based on the following statistical positions. 
Let there be a set of links between elements of a given strength $R_{1}, R_{2}, \ldots R_{i}, R_{m}$, the probabilities of which are not equal and presented as $P_{1}, P_{2}, \ldots P_{i}, P_{m}$.

As a result of the external load action, we can get the combination of the destructed links that contains an $n$ set of $m$ links. Among them, let it be $n_{1}$ links $P_{1}, n_{2} \operatorname{links} P_{2}, n_{n}$ links $P_{n}$. The probability of each link is determined $P_{i}=\frac{n_{i}}{n}$.

All destructed links would be based on the complete system of unplanned (accidental) events:

$$
\sum_{i=1}^{m} P_{i}=1
$$

Further, from formula (3) in view of the relation (1) it follows that the average survivability of the surface mine object is

$$
R=\frac{1}{M_{v}}=\frac{1}{\prod P_{n}} .
$$

We suppose that in all $n$ element groups of the mine surface object, the average reliability levels $p_{n . c p}$ are the same and equal to $p_{n}$. In this case, the average survivability of the building by definition is expected to equal to the normal value $R_{H}$, and formula (4) takes the form of $R_{H}=1 / p_{H}^{n}$, which determines the normal, satisfactory, and limit level of structural elements. This has resulted in

$$
\begin{aligned}
& p_{H}=\sqrt[n]{1 / R_{H}} ; \\
& p_{y}=\sqrt[n]{1 / R_{y}} ; \\
& p_{y}=\sqrt[n]{1 / R_{n}} .
\end{aligned}
$$

Below is the research of the dependence of the reliability of elements on their quantity. We use data on the physical wear of industrial objects of the Kryvbas mining enterprises, which were obtained by the employees of the Kryvyi Rih National University at survey of over 1000 objects. In our case, we present data for the A-1 group objects related to the production processes.

For a more in-depth visualization, the data on physical wear of the objects under study are divided into four groups and visually represented in Fig. 1.

For practical application, the theoretical curve shown in Fig. 2 is divided into four linear sections, at the junction of which the physical wear varies discontinuously. It is known [4] that any change in the rate of wear indicates the change in the technical condition of the mine surface object. Investigations of the object survivability of different service life and the subsequent analysis of the study results served to define the location of the joint points (threshold values of survivability levels).

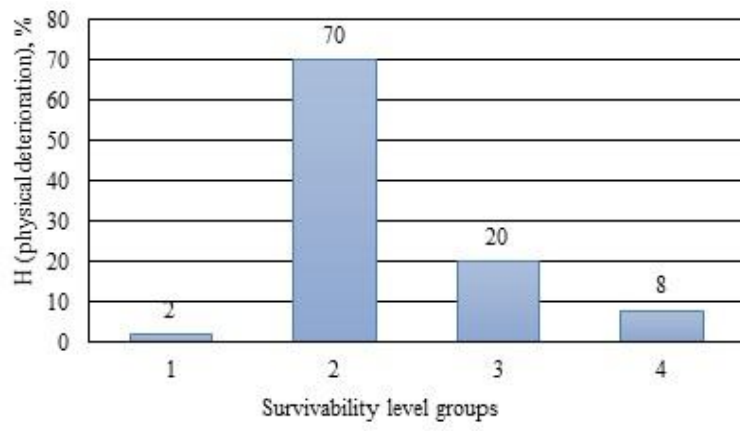

Fig. 1. Dividing the physical wear of the diagnosed objects into four groups

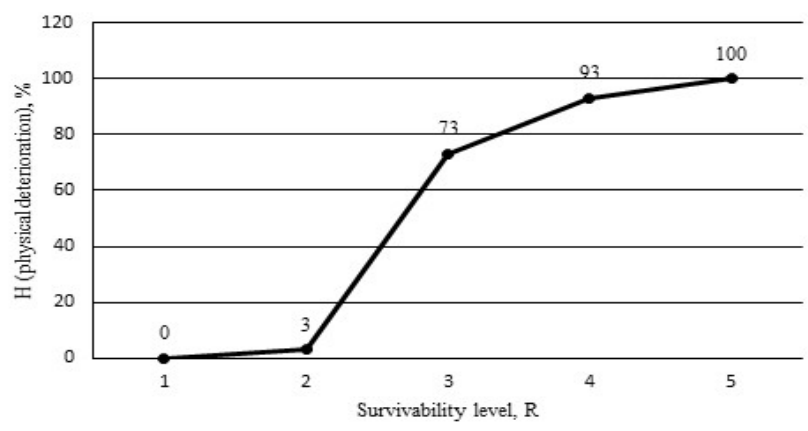

Fig. 2. Model degradation of the bearing construction of the mine object and threshold values of survivability

To achieve the desired diagram "wear-survivability", we determine the reliability levels by formula (5).

The operating time of the surface object until a satisfactory survivability $R_{\text {sat }}=3$ (satisfactory) determines $T_{\sigma}$ as an upper limit of the safe resource of the object. The technical state of the surface object 
at this time interval can be treated as safe. When the object reaches an unusable survivability $R_{\text {uns }}=73$ (unusable), the wear is more than $60 \%$. At such wear rate, repair works of the building are required [5]. Otherwise, the survivability continues to grow and reaches the next critical value $R_{\text {crash }}=93$ (crash), which determines the marginal resource of the surface object.

The survivability degree of the mine surface object depends on the technical condition of the groups of elements that form the entire structure of the facility. The number of such groups, as well as the number of structures in buildings and constructions are large. Determination of actual levels of the reliability at survey of structures is time-consuming and costly. The quantity of expert works will be drastically reduced if the principles of qualimetry are used as a basis for assessing the technical condition of the bearing framework of the mine surface object. For this purpose, the most and least defective constructions are found in each group, followed by an expert evaluation of their compliance with the project requirements in terms of ensuring their strength, rigidity and stability $[6,7]$.

The model selection of physical wear of the mine surface object is justified by studies of the resource of structures in the reliability theory $[1,2,8,9]$.

To predict the safe residual resource of the mine surface object, the dependence of physical wear on time is taken in the form of exponents

$$
\Phi(T)=1-\exp \left(-i \cdot T_{\text {factual }}\right)
$$

where $i$ is the physical wear intensity of the mine object.

At $T_{\text {factual }}$, the wear is known and is equal to $\Phi=\Phi\left(T_{\phi}\right)$. By comparing the obtained equations, we can get

$$
\begin{aligned}
& 1-\exp (-k R)=1-\exp \left(-i \cdot T_{\text {factual }}\right) ; \\
& i=\frac{0.0175 R}{T_{\text {factual }}} .
\end{aligned}
$$

Safe residual resource $T_{\text {safe }}$ is determined by the formula $T_{\text {safe }}=T_{\text {permissible }}$, where $T_{\text {permissible }}$ is the start time of the surface mine object construction until it reaches the maximum permissible survivability $R_{\text {permissible }}$. The time $T_{\text {permissible }}$ with the intensity is determined from equation, (7), if to take that $\Phi_{\lim i t}=0,50$ or $\Phi_{\lim i t}=0,20$. As a result, the formulas for determining the safe residual life (srl) and the safe resource without a safety overhaul (swro) are the following, respectively:

$$
\begin{aligned}
& T_{\text {srt }}=\frac{0.0525}{i} ; \\
& T_{\text {swro }}=\frac{1.2775}{i} .
\end{aligned}
$$

According to the formula (8) we can predict the safe resource of the mine surface object at the end of its construction. For this, the value $T_{\text {factual }}$ should be equal to zero. When $R_{\text {factual }}>R_{\text {permissible }}$ the safe resource of the mine surface object is completely exhausted.

The maximum service life of the mine surface object $T_{\text {critical }}$ can be predicted from the condition that the wear rate is known and equals $\Phi_{\text {critical }}=0,80$. Here, the time $T_{\text {critical }}$ can also be determined from the equation

$$
T_{\text {critical }}=\frac{1.6275}{i} \text {. }
$$

Formula (9) is valid if repair and restoration work has not been carried out at the site

If repair and restoration works at the site are not carried out by the end of a safe resource, the resistance of its elements under loads (especially emergency ones) is reduced and may lead to an accident.

Conclusions and further research. A model law of the operated building state is obtained in the form of the dependence of the wear of the bearing building constructions on its degree of survivability. We have determined the threshold values of the survivability, at which the surface object goes to a qualitatively different state like normal-satisfactory, satisfactory-unsuitable, and unsuitableemergency.

The proposed methodology is confirmed to be used in assessing the survivability degree, the technical condition and the safe residual resource. 


\section{References}

1. Holicky M. Risk and reliability acceptance criteria for civil engineering structures. / M. Holicky, D. Diamantidis, M. Sykora // In: Structural Reliability and Modelling in Mechanics, At Ostrava, Czech Republic. - 2016.

2. Holicky M. Determination of target safety for structures. In: Haukaas, T. (Ed.). / M. Holicky, D. Diamantidis, M. Sykora // Proceedings of the 12th International Conference on Applications of Statistics and Probability in Civil Engineering, Vancouver, Canada. - 2015. https://open.library.ubc.ca/cIRcle/collections/53032/items/1.0076258

3. Holicky M On standardization of the reliability basis of structural design. In: Haukaas, T. (Ed.) / M. Holicky, D. Diamantidis, V. Johan // Proceedings of the 12th International Conference on Applications of Statistics and Probability in Civil Engineering (ICASP12), Vancouver, Canada, July 12-15. - 2015. https://open.library.ubc.ca/cIRcle/collections/53032/items/1.0076062

4. Holicky M. Probabilistic Assessment Of Industrial Heritage Structures: Framework And Case Study. / M. Holicky, M. Sykora // In: WIT Press, Ashurst Lodge, Southampton, UK. - 2013. - Volume 131. - p. 171 - 182. DOI: 10.2495/STR130151

5. Chaminda Konthesinghaa, K.M. Reliability based vulnerability modelling of metal-clad industrial buildings to extreme wind loading for cyclonic regions. / K.M. Chaminda Konthesinghaa, G. Mark, Stewarta, R. Paraic, G. John, H. David // In: Journal of Wind Engineering and Industrial Aerodynamics. - 2015, - Volume 147. - p. 176-185. DOI: 10.1016/j.jweia.2015.10.002

6. Stupnik N. Modeling of stopes in soft ores during ore mining theme. / N. Stupnik, V. Kalinichenko, V. Kolosov, S. Pismennyy, A. Shepel // Metallurgical and mining industry. 2014. - №3, pp. 32-37.

7. Бровко Д. В. Дослідження конструкцій металевого арочного кріплення в умовах криворізького залізорудного басейну. / Д. В. Бровко, В. В. Хворост // Геотехническая механика: Межвед. сб. науч. тр. - Днепропетровск: ИГТМ НАНУ. - 2015. - №123. - С. 99-106.

8. Андреев Б. М. Визначення надійності та обгрунтування параметрів об'єктів на поверхні шахт з урахуванням переходу на полегшені огороджувальні конструкції / Б. М. Андреев, Д. В. Бровко, В. В. Хворост // Металлургическая и горнорудная промышленность. - Днепропетровск, 2015. - no. 12. - С. 378-382. DOI: 10.13140/RG.2.2.30779.31529

9. Бровко Д. В. Оценка риска надежности конструкций эксплуатируемых объектов горнопромышленного предприятия / Б. Н. Андреев, Д. В. Бровко, В. В. Хворост // Сборник научных трудов: БНТУ. - Минск, 2013. - т.1. - С. $180-190$

10. Ступник Н.И. Разработка рекомендаций по выбору типа крепления горных выработок и сопряжений в условии урановых шахт ГП "ВОСТГОК"/ Н.И. Ступник, М.Б. Федько, В.А. Колосов, С.В. Письменный // Науковий вісник НГУ. - 2014. - № 5. - С.21-25.

11. Golik, V. Feasibility of using the mill tailings for preparation of self-hardening mixtures. / V. Golik, V. Komashchenko, V. Morkun / Metallurgical and Mining Industry. - 2015. - No 3, p.p. 38-41.

12. Golik, V. Innovative technologies of metal extraction from the ore processing mill tailings and their integrated use. / V. Golik, V. Komashchenko, V. Morkun // Metallurgical and Mining Industry. - 2015. - No 3, p.p. 49-52.

13. Golik V. Geomechanical terms of use of the mill tailings for preparation. / V. Golik, V. Komashchenko, V. Morkun // Metallurgical and Mining Industry. - 2015. - No 4, p.p. 321-324.

14. Stupnik, N.I. Testing complex-structural magnetite quartzite deposits chamber system design theme. / N.I. Stupnik, V.A. Kalinichenko, V.A. Kolosov, S.V. Pismenniy, M.B. Fedko // Metallurgical and mining industry. - 2014. No 2, pp 88-93.

15. Федько М.Б. Экономические аспекты перехода на бестротиловые взрывчатые вещества при подземной добыче руд в Криворожско бассейне / М.Б. Федько, В.А. Колосов, Е.А. Калиниченко, С.В. Письменный // Науковий вісник НГУ. - 2014. - № 4. - С.79-84.

The editorial board received a manuscript on 19.04.2018

\section{УДК 624.03}

С.В. КОЛЕСНІЧЕНКО, Ю.В. СЕЛЮТІН, кандидати техн. наук, доценти, К.Б. МНАЦАКАНЯН, ст. викладач

Донбаська національна академія будівництва і архітектури

\section{ВИМОГИ ДО ЕКСПЕРТІВ 3 ТЕХНІЧНОГО ОБСТЕЖЕННЯ БУДІВЕЛЬ І СПОРУД}

Мета. Метою даної роботи є запропонувати переглянути стандартні вимоги до фахової кваліфікації претендента на проходження професійної атестації за видом робіт «Експертиза та обстеження у будівництві» та «Технічного нагляду». Ввести регулярне проходження експертами курсів підвищення кваліфікації за фахом. Запропонувати внесення категорій до сертифікату експерта 3 обстеження так як у сертифікації експерта 3 технічного нагляду, залежно від класу наслідків об'єкта будівництва.

Методи дослідження. Аналіз кваліфікаційних вимог, а саме їх достатність, до виконавців робіт для проходження професійної атестації за видом робіт експерт з обстеження будівель і споруд.

(c) Колесніченко С.В. Селютін Ю.В. Мнацаканян К.Б., 2019 